\title{
Thoughts on the Professional Development of College Counselors in the New Era Based on the Intrinsic Level of Individuals
}

\author{
Huang Haiyan \\ Sichuan TOP IT Vocational Institute, Sichuan, China, 611743
}

Keywords: Higher education, counselor, professional construction

\begin{abstract}
In the new era, with the expansion of the enrollment of higher education in China, the ideological education construction and all-round development of college students will become more and more difficult and the problems faced by college counselors will become more severe. College counselors are the backbone of the ideological and political education of college students in higher education, shouldering the heavy responsibility of successors and builders of socialist undertakings. This requires strengthening the construction of college counselors and improving the overall quality of counselors. This paper makes a preliminary analysis on the professional construction of college counselors based on the experience and problems in practical work.
\end{abstract}

\section{Introduction}

The all-round development of college students in the new era and the construction of ideological and political education have become the main tasks of all current universities. As the international and domestic situation continues to produce new changes and the current information dissemination speed is fast, various information has a great impact on contemporary college students' thinking and values and the ideological education construction of college students will be more severe. As the most direct bridge between the school and the students, the counselor is the most extensive and most in-depth life tutor and healthy growing intimate friend. He also shoulders the functions of management, teaching and service assigned by the school. and so, the ability and quality of college counselors are directly related to the effectiveness of student management and ideological education. Whether professional college counselors are professional will be the key to determining whether colleges and universities can solve the new challenges of student management and ideological education $^{[1]}$.

\section{The necessity of professionalization of college counselors}

College counselors have very special jobs. They are different from basic courses or professional class teachers. They must not only guide the ideological and political education of college students, but also solve various problems encountered by college students in their study and life. With the development of the economy and the progress of the times, college students may have more and more problems, including objective problems, such as employment, study, economic issues and 
various psychological problems. If these problems are not discovered and resolved in time, they will cause serious hidden dangers. Therefore, the reality of the requirements of the counselor is very strict, is no longer a simple transactional management, but must have targeted guidance and services. This requires counselors to become professional and professional personnel and assume the responsibility of ideological and political guides, psychological counselors and employment counselors $^{[2]}$.

\section{Understanding level of the professionalization of college counselors}

\subsection{Role orientation of college counselors}

College counselors play an important role in the organization and implementation of daily ideological and political education and management of college students. They are the instructors and guides for the healthy growth of college students. They are important organizational guarantees for strengthening and improving the ideological and political education of college students and maintaining the stability of colleges and universities. It is a close friend of college students to develop a healthy outlook on life, world outlook and values from the aspects of being a person, doing things and doing learning ${ }^{[3]}$.

\subsection{Main duties of the counselor's work}

Help college students to establish a correct world outlook, outlook on life, values, establish a common ideal and firm belief in the path of socialism with Chinese characteristics under the leadership of the Communist Party of China and realize the great rejuvenation of the Chinese nation; help college students develop good moral qualities; Master the ideological and political status of college students; implement relevant work for students with financial difficulties; actively carry out employment guidance and service work; guide students' party branch and class committee construction, do a good job in student backbone training and stimulate students' enthusiasm and initiative ${ }^{[4]}$.

\subsection{Connotation of the professionalization of the counselor team}

In order to promote the construction of the professional team of counselors, the university must first deepen the counselor's understanding of the professionalism. The basic connotations include: (1) professional jobs (2) professional staff (3) scientific Assessment management (4) Institutionalized education and training (5) Strict reward and punishment system. The understanding level of professional development of college counselors is shown in Figure 1.

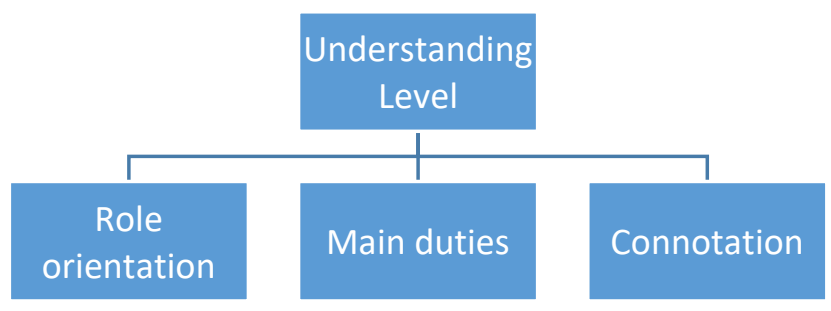

Figure 1 Understanding level of professional development of college counselors 


\section{Problems in the professional construction of the in-house level of college counselors}

\subsection{Insufficient number of counselors}

Insufficient number of counselors is one of the outstanding problems in the long-term construction of counselors. Due to the objective conditions such as the number of classes and the number of students, some counselors are responsible for the number of students who manage students. The higher classes will cause problems such as losing their jobs and being too sloppy, not to mention the ideological and political work of students. real. Insufficient staffing, resulting in increased work intensity and the counselor's personal energy is limited, the time spent on scientific research activities and improving their own ability will be reduced, which affects the combat effectiveness of the counselor team to some extent, thus becoming a constraint on college students ${ }^{[5]}$. The main factors for improving the level of ideological and political education. The number of college counselors is shown in Figure 2.

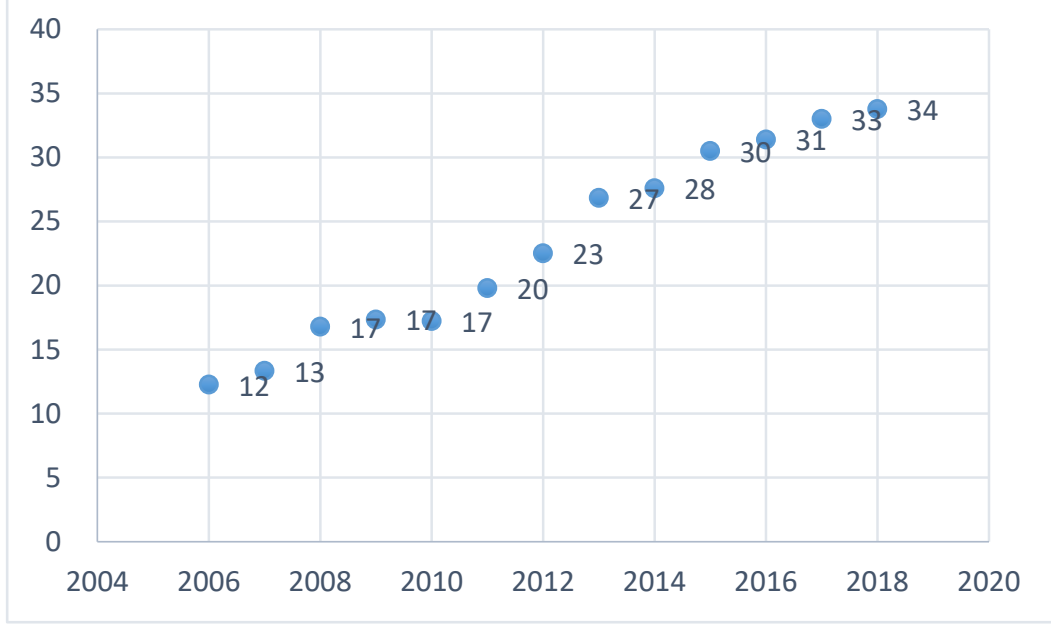

Figure 2 Number of college counselors

\subsection{The team structure is unreasonable}

The age structure is unreasonable and the academic structure and professional title level are low. At present, most of the college counselors in China are undergraduate graduates, a small number of them are masters and very few are experienced (deputy) professors with doctoral degrees or above. The main reasons for the low level of counselor's academic qualifications and professional titles are as follows: First, colleges and universities take into account the special nature of counselors' work tends to use newly graduated undergraduates as hiring people, hoping to increase their experience in their work without taking academic qualifications. The first consideration is that the majority of the candidates for the job of counselors are undergraduate graduates and there are few experts or scholars with higher academic qualifications. The third is more transactional work and the time for study or training is relatively small.

Professional mix is not reasonable. According to the duties of the counselors, the majors of the counselors should be the theory and method of ideological and political education, but the proportion of counselors who meet this requirement is relatively small. Nearly half or more of the counselors' professions are not related to ideological and political education, which has resulted in the unscientific discipline structure of the counselors and the low professional quality. According to the role of the party and the government in the role of educators, administrators and service providers, counselors must not only be able to do a good job in the ideological and political 
education of college students, but also be able to cope with the psychological, employment and difficulties of college students. The handling is easy, so the professional quality requirements of the counselors are relatively high. Only professional counselors can provide personalized and effective services and guidance to students.

\subsection{The management system is not sound}

At this stage, the counselors of most universities in China implement dual management. The work arrangement and business guidance are the responsibility of the student department, while the personnel relationship, year-end assessment and organizational relationship are the responsibility of the college. As the administrative department of the school, the student office is not a teaching management organization. The guidance for the counselor's work is also inclined to the administrative aspect. As the teaching management department, the colleges pay more attention to teaching and scientific research and to some extent ignore the student work of the counselors. Although colleges and universities have made great improvements in this respect in recent years, there are still many problems in the orientation and management of counselors' duties.

\section{Suggestions on Improving the Professionalization of Counselors in Colleges and Universities at the Intrinsic Level of Individuals}

\subsection{Further strengthen the understanding of the importance of the construction of counselors}

Colleges and universities generally have insufficient understanding of the importance of professionalization and specialization of counselors. Some colleges and universities have not placed the construction of counselors on the same level as other professional teachers.

\subsection{Establish a sound guarantee mechanism for college}

Establishing a sound guarantee mechanism for college counselors includes not only the selection of a sound counselor team, but also the support mechanism for the counselor's politics, working conditions and living conditions. College counselors work in the front line of college students' ideological and political education. They have a large workload, heavy tasks and need to learn more. They need a good policy environment and clear recognition in terms of treatment and professional titles, so that they can ensure that they have good Working conditions, broad development space and maximizing their enthusiasm.

\subsection{Improve the counselor training system}

The college counselor training system is an important way for counselors to learn. It can not only improve the professional skills of counselors, but also strengthen the communication between counselors. The training should focus on systemic, long-term, diversity and effectiveness. The content of the training should be diversified, including the professional knowledge training of the counselors, as well as training on various psychological issues and employment issues, with a view to improving the practical application ability of the counselors.

\subsection{Improve the counselor's assessment and incentive system}

Schools should establish a comprehensive assessment mechanism, a promotion mechanism for posts, establish an incentive mechanism for fair competition and timely adjust the goals and routes of counselors' careers to promote their further development. Under the establishment of a fair 
competition mechanism, rational use of counselors' resources and optimize the team of counselors, focusing on the promotion of excellent performance counselors, which enhances the enthusiasm of counselors, facilitate the absorption of fresh talents, accelerate the construction of ideological education for college students and achieve the team's Sustainable development.

\section{Conclusion}

In short, under the new situation of accelerating the modernization process and paying more attention to the cultivation of talents in colleges and universities, the professional construction and professional construction of college counselors are particularly important. Only by continuously strengthening the professional construction of the counselor team can we adapt to the ever-changing development trend of contemporary college students and train qualified builders and reliable successors for socialism.

\section{Acknowledgement}

Humanities and Social Sciences project of Sichuan provincial education department in 2018. 18SB0518

\section{References}

[1] Karen Jeong Robinson,Josipa Roksa. Counselors, Information, and High School College-Going Culture: Inequalities in the College Application Process [J]. Research in Higher Education, 2016,57(7).

[2] Ora Peleg,Chen Deutch,Orrie Dan. Test anxiety among female college students and its relation to perceived parental academic expectations and differentiation of self[J]. Learning and Individual Differences,2016,49.

[3] Chunhua, Hu. Based on college counselors work performance of the WSR system research[P]. ,2013.

[4] Nie Xue-lin, Chen Jie. Research on the Impact of Job Resources and Organizational Justice on College Counselors' Working State[P]. Management and Service Science (MASS), 2011 International Conference on,2011.

[5] Yanjun, Xu. College counselors talk to the educational effect[P]. Consumer Electronics, Communications and Networks (CECNet), 2012 2nd International Conference on,2012. 